\title{
Construction frameworks
}

in the public sector Do they deliver what they promise?

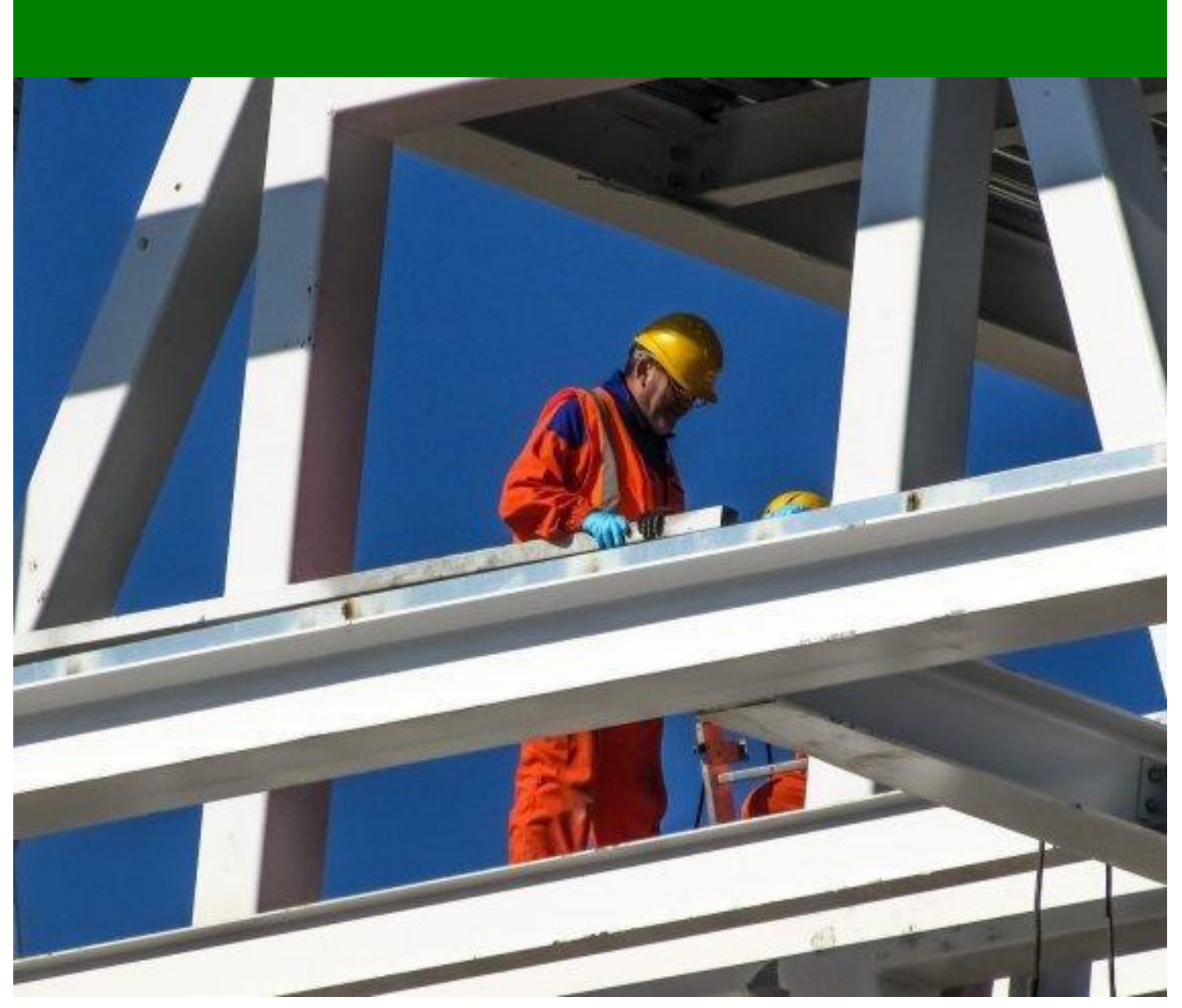

Terence Y M Lam Keith S Gale

October 2021
PROPERTY RESEARCH TRUST 


\section{Construction frameworks in the public sector}

\section{Do they deliver what they promise?}

Published by the Property Research Trust.

Contact: info@propertyresearchtrust.org

The views expressed are those of the authors and are not necessarily those of the Property

Research Trust or its trustees. Neither the authors, nor the Property Research Trust, nor its trustees, accepts any liability arising from the use of this publication.

Copyright Property Research Trust 2021.

All rights reserved. No part if this publication may be reproduced or transmitted in any form or by any means, electronic or mechanical, including photocopy, recording, or any information storage and retrieval system, without permission in writing from the publisher. The Property Research Trust is a charity registered in the UK and regulated by the Charity Commission, registered number 1085587. Companies House registered number 4044051. Registered office 5th Floor, 167-169 Great Portland Street, London. W1W 5PF.

\section{About the Property Research Trust}

Formerly the RICS Research Trust, we are an established grant-awarding charity, supporting research across the disciplines of land, real estate and construction. We have a strong track record of delivering and disseminating high quality, independent knowledge and future thinking. We fund research globally.

propertyresearchtrust.org 


\section{Authors}

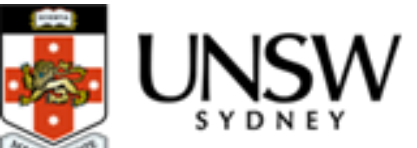

Terence Yat Ming Lam (PhD, MA, BSc, FRICS) is a Senior Lecturer in Property and Development) at the School of Built Environment, University of New South Wales. He holds his first degree in Building Surveying, an MA in Building Rehabilitation Studies, and a PhD in Property and Construction Studies from Department of Real Estate and Construction, the University of Hong Kong. His research and teaching interests lie in construction procurement practice, construction risk management and contingency, as well as asset and facilities management, specialising in performance assessment, modelling and prediction of construction consultants and contractors for procurement and outsourcing processes. He is a fellow of the Royal Institution of Chartered Surveyors and has years of experience in professional practice in property and construction. See research profile and publications via https://www.ada.unsw.edu.au/our-people/yat-lam.

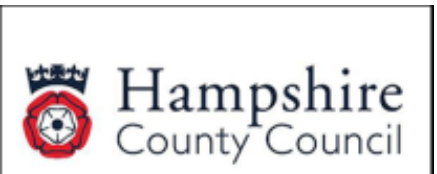

$£ 45 \mathrm{~m}$ within a capital annual programme of $£ 100 \mathrm{~m}$ per annum, as well as providing commercial advice on frameworks and term contracts for works and services up to $f 500 \mathrm{~m}$ in value. He is a member of the Royal Institution of Chartered Surveyors and a former Chartered Arbitrator. He achieved his Professional Doctorate in Construction Frameworks Studies from Anglia Ruskin University and is a Visiting Fellow at the Department of Engineering \& Built Environment.

\section{Reference}

Please reference this report Lam Y. M. and Gale K. S. Construction frameworks in the public sector: do they deliver what they promise? London: Property Research Trust, 2021: https://doi.org/10.52915/SBUK7331 


\section{Contents}

Foreword from the Chair of the Property Research Trust

Key points

Executive summary

6

Introduction: research aims and scope

9

Construction frameworks

Performance drivers: a literature review

The research

Results and discussion

Conclusions and recommendations

References

Acknowledgements 


\section{Foreword from the Chair of the Property Research Trust}

The need for governments around the world to invest in the built environment has never been greater. Populations are growing, ways of living and working are changing, and the climate emergency means a huge requirement for buildings that are more energy efficient and more resilient to the challenges posed by climate change. But at the same time, public finances everywhere are stretched, and have been made more so by the global Covid-19 pandemic. So, improving the way in which the public sector procures construction work has to be a priority. This report makes an important contribution to that topic, by providing rigorous, quantitative analysis of the benefits that can be obtained by the use of Construction Framework contracts, in preference to ad hoc 'open tender' arrangements. The analysis in this report is original and, I believe, of importance to us all. I am delighted that the Property Research Trust has been able to provide a home for this research.

Sarah Sayce

Chair

Property Research Trust 


\section{Key points}

- The research in this report demonstrates that the use of Performance Frameworks for the procurement of construction projects by public sector organizations in the UK (specifically, in England) leads to significantly improved outcomes in terms of time, cost, quality, sustainability and closer relationships, than the traditional 'open tender' approach of procuring discrete projects, individually.

- Our research identifies the factors that lead to such improvements. We label these: supplier's task performance factors (project staff, execution approach, competence of firm and structure of firm); supplier's contextual performance factors (trust and collaboration, culture and conscious behaviour); and client's organisational factors (incentives, performance monitoring, procurement approach and communication).

- We offer a performance improvement model that will help project managers to select the most appropriate suppliers at the procurement phase, to achieve successful project outcomes.

- Our model can also be used to drive project performance further, by adopting client's organisational factors during the procurement and construction phases.

- By applying our research conclusions, suppliers will be able to focus on communicating their strengths in the relevant aspects of task and contextual performance for technical tender proposals, and so increase the value of their services and the probabilities of winning work.

- $\quad$ And our analysis can also be used by policy makers to help in drafting regulations and legislation on formal frameworks, in ways that will improve the delivery of policy objectives. 


\section{Executive summary}

\section{Background}

Construction frameworks account for billions of pounds of public sector expenditure within the UK and throughout wider Europe, with this method of procurement being specifically recognised by the UK Government as an integrated approach towards improvement in efficiency outcomes in terms of cost, time and quality.

Public sector frameworks were formally introduced into European legislation through EU Directive 2004/18/EC of the European Parliament for coordination of procedures for the award of public works contracts, public supply contracts and public service contracts.

A prime objective of using a framework is the potential benefits that may occur due to the stronger relationships arising from longer term arrangements using engagement with fewer, but carefully chosen suppliers. This is distinctive from 'open tender' arrangements where a supplier is chosen for a single project in isolation.

The opportunity to provide programmes of work over longer periods allows relationships to be established that encourage collaboration. As such, this procurement approach is particularly suitable for high-risk, high-spend construction and maintenance programmes, often found with civil engineering works, housing, education and public buildings. A framework agreement provides an overarching 'umbrella' contract where projects are separated into individual 'work packages' procured at a call-off stage throughout the period of agreement, which is currently set (under current UK and European legislation) for a maximum of four years.

Framework agreements have generally received positive support from central UK government departments and are used by many other public sector organisations. Nonetheless, they have not received universal acceptance by all parties involved with the construction process. Criticisms have arisen from the lack of transparency and incorrect application of a framework, while others challenge the economic and competitive effectiveness of frameworks.

\section{Research aims and objectives}

There is a dearth of in-depth research on the cause and effect of relationships from long-term collaborative frameworks and performance of construction projects. This new research investigates the impact of construction frameworks on project outcomes and models the performance drivers to augment current relational contracting and project management knowledge

The research investigates whether the use of frameworks for public-sector construction can result in significant improvements for project outcomes which can then provide the basis for a performance improvement model. The investigation includes questionnaire survey and interview data collected between March 2019 and February 
2020, based upon recent civil engineering and building construction frameworks procured within the geographical area of England under the Public Contracts Regulations 2015 legislation. Within these aims, the study undertook to identify project outcomes and performance drivers as follows:

Determine whether project outcomes achieved within construction frameworks were significantly different from those of traditional 'discrete' projects.

Examine causal relationships between project outcomes and performance drivers.

Develop a performance improvement model for driving project outcomes.

\section{Research methods}

The project commenced with a literature review of appropriate performance drivers, based on job performance and project management theories. A performance improvement model was then developed from the following hypotheses, formulated through job performance and project management theories:

RH1: Building construction and civil engineering frameworks significantly improved project outcomes of time, cost, quality, sustainability and closer relationships with clients.

RH 2: Individual project outcomes were positively correlated to the level of task and contextual performance factors, for example, project staff, trust and collaboration, etc.
RH 3: Individual project outcomes were positively correlated to the level of client's organisational factors, for example, incentives, performance monitoring, etc.

Testing of the hypotheses and validation of the performance improvement model was performed, using data and insights collated from the following sources:

An expert pilot survey conducted with three senior client construction managers experienced with managing construction frameworks to determine project outcomes and performance factors and refine the research hypotheses.

A quantitative independent-samples t-test conducted to verify $\mathrm{RH} 1$, using 70 sets of data on project outcomes collated from a questionnaire survey of front-line project managers involved with building construction and civil engineering frameworks.

A quantitative hierarchical regression analysis conducted to address $\mathrm{RH} 2$ and $\mathrm{RH} 3$, also based on the 70 data sets of performance influences collated from the questionnaire survey.
A qualitative multiple-case study conducted on eight typical building construction and five civil engineering framework projects in order to provide further explanation and evidential support for the casual relationships ( $\mathrm{RH} 2$ and $\mathrm{RH} 3$ ) revealed by the quantitative regression study.

Findings and benefits to stakeholders 
The overall results from the quantitative and qualitative studies confirmed assumptions made by the hypotheses and performance improvement model.

These findings, apart from validating a performance model that may be used in other applications, allow transfer of results into practical, policy and theoretical implications to benefit stakeholders within a public-sector environment. In particular, the model is of interest to the following groups:

Framework managers: Reference to the task and contextual performance factors of the performance model will allow framework managers to select the most appropriate suppliers at the procurement phase to achieve project outcomes. The model can also be used to drive project performance by adopting a client's organisational factors at the procurement and construction phases.

Suppliers: Identification and communication of their relative strengths with clients together with task and contextual performance for technical proposals allows suppliers to add value to their services and increase the chances of winning work.

Public decision makers: The findings confirm potential benefits from the use of construction frameworks in terms of time, cost, quality, sustainability and closer relationships with clients. Such findings provide confidence to public decision-makers when setting up formal frameworks to ensure these align with UK central government policy objectives.

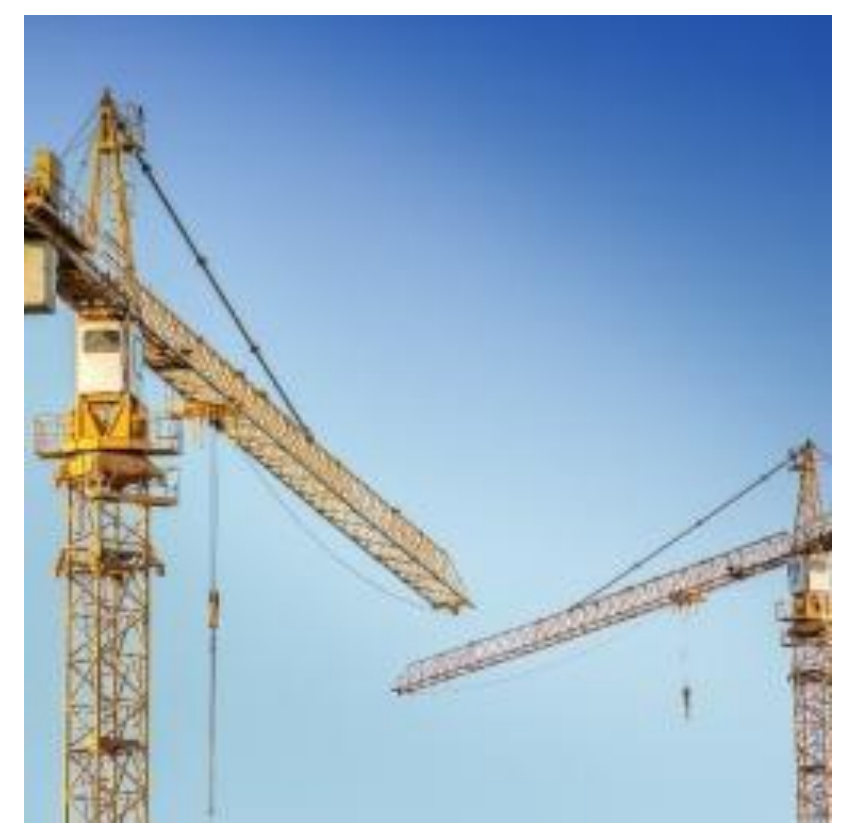




\section{Introduction: research aims and scope}

\section{$1.1 \quad$ Background}

Within the United Kingdom, construction frameworks account for billions of pounds of public sector expenditure on projects such as schools, hospitals, housing, defence estates and infrastructure, including highways, railways and utilities (ONS, 2021). McCracken (2017) reported that spending by local authorities on highways and transportation (maintenance, improvement and construction) alone was $£ 4.24$ billion in 2017/18. Frontier Economics (2015) indicated that the Higher Education sector in England spent $£ 20$ billion on capital expenditure between 2005/06 and 2013/14, with the bulk of capital investment $(77 \%)$ in buildings. Owing to the sheer volume and repetitive nature of this type of work, construction frameworks are a popular method with which to engage suppliers and undertake projects.

Public-sector frameworks were formally introduced into European legislation through the EU Directive 2004/18/EC of the European Parliament for coordination of procedures for the award of public works contracts, public supply contracts and public service contracts, and subsequently incorporated into UK law. Frameworks are formally established through a framework agreement, which instigates a legal relationship between a client and suppliers which endures in the UK system for a term of four years. This fixed term provides a period during which understanding between participants can be nurtured, allowing overall levels of service rather than individual isolated packets of performance from single projects. Such characteristics make frameworks particularly suitable for high-risk, highvalue, long-term construction and maintenance programmes, such as those found with public-sector housing, education, public buildings, highways and other infrastructure (Constructing Excellence, 2019a). Procurement of goods and services (set at prescribed minimum values) is also consistent between all public authorities irrespective of the individual authority's constitution.

As with other relational projectdelivery contracting arrangements, such as project partnering, project alliance and integrated project delivery, frameworks have been developed as an effective production arrangement for improving delivery through collaboration and integration of a project team (Lahdenpera, 2011). The use of construction frameworks was identified by the UK Government's Construction Strategy 2025 as an integrated procurement path that, it is claimed, can be used to deliver significant cost and time savings (BIS, 2013).

A prime objective of using a framework is the potential benefit that may occur, due to stronger 
relationships through longer term arrangements using fewer suppliers The Local Government Association (2020) summarised economic and project management benefits of construction frameworks as follows:

- effective frameworks can offer distinct benefits over traditional procurement for projects by facilitating a more integrated solution based on continuing and closer relationships with a limited number of suppliers.

- early engagement of suppliers in the design process contributes to reduce cost and increase whole life value.

This contrasts with 'open tender' arrangements in which a supplier is chosen for a single project. The opportunity to provide suppliers with visibility of programmes of work stretching over long periods allows the establishment of relationships that encourage collaboration initiatives, as suggested by Latham (1994) and Egan (1998).

However, although framework agreements generally have received support from central government (Business and Enterprise Committee, 2008), they do not have universal acceptance by all parties involved with the construction process. Criticisms arise through incorrect application of a framework, while others challenge the economic effectiveness of frameworks. As an example, British Airports Authority's framework arrangements expired during 2009/10 and were replaced using elements of traditional tendering encompassing enlarged lists of suppliers effectively mirroring a traditional procurement model (Morgan, 2009).
Opponents question a framework approach, and argue that the costs of using complicated and extensive tendering procedures with minicompetitions outweigh any savings made due to lower initial engagement costs. Preparation of framework agreements using significant tender documentation and extensive submissions of tenders are often criticized as wasteful by detractors. Construction industry analysts report a number of private sector clients rejecting construction frameworks in favour of traditional competitive procurement practices (Tennant and Fernie, 2012; Stanford and Molenaar, 2018).

\subsection{Research aims and objectives}

Despite the widespread adoption of construction frameworks, there is scarce empirical evidence about their performance outcomes, or the effectiveness of this method of procurement (Patrucco, et al., 2017).

Some evidence has been generated by a case study conducted within a UK County Council, to investigate the impact of construction frameworks on highways maintenance. Results from this case study demonstrated that the framework delivered: significant improvements in cost (reduction in total production and transaction costs), time (completion on time) and quality (less defects and better health and safety), and that performance was driven by long-term relationships, stronger communication, financial and non-financial incentives, the use of key performance indicators and competent contractors, 
standardisation of documentation and simplified evaluation procedures for tendering (Lam and Gale, 2014a; 2014b; 2014c).

That case study provides a baseline from which to undertake further research, covering a wider geographical area and with the scope widened to include building construction projects, so that data and results can be collated which represent a wider public sector environment.

This research accordingly seeks to investigate that wider scope, and:

Determine whether the use of frameworks for public-sector construction can result in significant improvements for project outcomes, and if so then:

Develop a performance improvement model to drive these outcomes further.

Within these aims, the research undertakes the following objectives:

Identifying project outcomes and performance drivers, following a literature review and a pilot questionnaire with a selected number of practitioners within a public-sector environment.

Determining whether project outcomes achieved by framework projects are significantly different from those of traditional 'discrete' projects. Examining the causal relationships between project outcomes and performance drivers.
Developing a performance improvement model for driving project outcomes.

Findings from this research should benefit not only public-sector construction clients and their professional advisors, but also contractors and other suppliers who can focus upon performance drivers in order to add value to their services.

\subsection{Research scope}

According to job performance and project management theories, positive project outcomes can be driven by both suppliers (contractors) and clients. In respect to the supplier's performance, the theory of job performance suggests that it can be influenced by task performance factors (the prescribed behaviours) related to job-specific task skills and contextual performance factors (additional behaviours) related to communication, coordination and teamwork skills (Masa'deh et. al., 2016). Time, cost and quality are the three major tenets of clients for construction projects (Walker, 2015) and in order to produce projects that satisfy their clients, construction professionals need to understand how client organisations operate and what organisational factors are used to improve these and other outcomes. Empirical studies suggest that there is a causal relationship between output performance and input drivers in production of services, and that mathematical regressions can be used to forecast project outcomes (Pallant, 2020). On the basis of these published studies, this research identifies project outcomes expected from construction 
frameworks and applies hierarchical regressions to establish the significant influences that can support the development of a performance-driving model.

The scope of this study is limited to project outcomes and performance drivers of construction frameworks within the context of public works capital and revenue contracts within the UK. The UK public sector comprises a wide range of organisations including central government, local authorities, the National Health Service, public utilities, housing associations and other similar entities. Further and higher education institutions are also included, and these are subject to public sector procurement legislation if more than $50 \%$ of a project cost is financed by public funding (Morledge et al., 2021).

In order to provide a stable base upon which to collect data, this study focuses upon construction frameworks adopted by two types of public-sector key players: local authorities and higher education authorities. In 2018/19 there were 343 local authorities (Unitary, County and District) in England (Local Government Association, 2020), and 111 publiclyfunded universities and university colleges, out of a total of 130 in the UK (Office of Students, 2018).

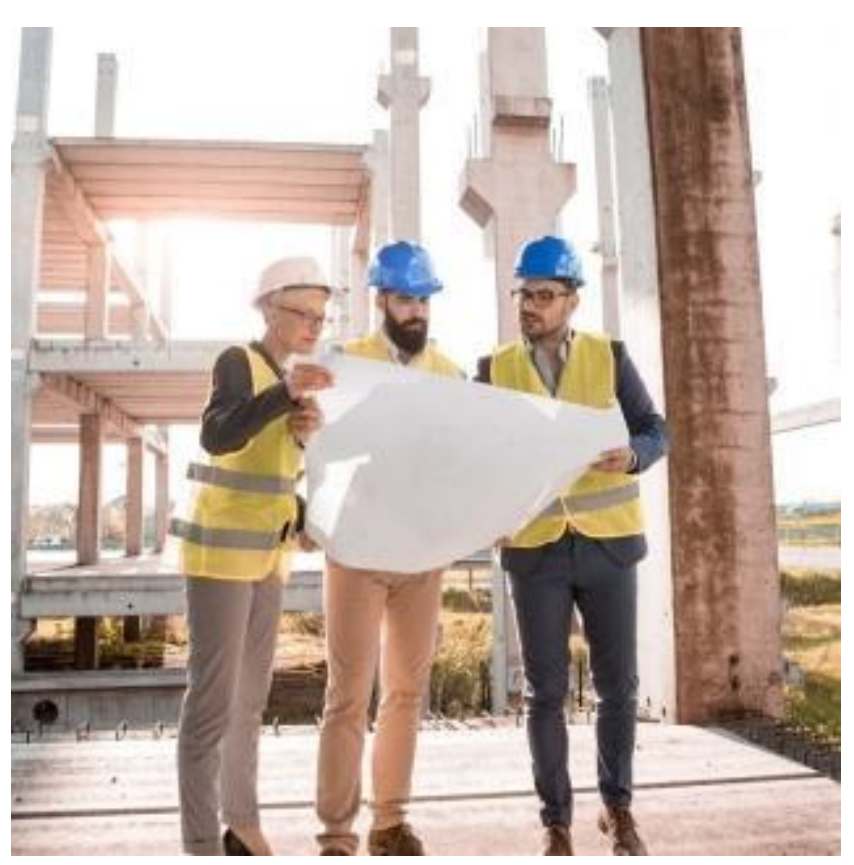




\section{CONSTRUCTION FRAMEWORKS}

\subsection{Broad characteristics}

A prime characteristic of a framework agreement is the term, i.e., the predetermined timescale for an agreement's operation (Constructing Excellence, 2019a). UK legislation dictates that, unless compelling reasons are demonstrated, the maximum term of a framework agreement shall be four years in duration. While some authorities would prefer agreements that exceed the four-year term, many recognise that this duration is sufficient to allow relationships and understanding to be nurtured where overall levels of service rather than individual isolated project performance can be focused upon.

A secondary characteristic of construction frameworks is that a client may enter into identical agreements with a restricted number of different suppliers effectively creating a selected community with which to deliver projects. Construction frameworks operate effectively where an authority knows they have a constant need for construction services, such as programmes of works, but are not sure of the extent or content of an individual project. A framework agreement provides an overarching 'umbrella' contract where projects are separated into individual 'work packages' and are procured at a call-off stage throughout the period of agreement. Most agreements reflect the structure of the industry, and therefore it is usual to find separate agreements for building construction and civil engineering works.

Building construction frameworks often cover a wide spectrum of minor and major works for new build, refurbishment and maintenance projects. The scope can span procurement of routine buildings, services such as plumbing and electrical maintenance works (paid on a time-charge basis) through to construction of standard building units of office space in various locations (paid through lump sum arrangements) (Constructing Excellence, 2019a). Likewise, the scope of civil engineering frameworks can include infrastructure enhancements such as highways railways and waterway improvements, asset enhancement, structural maintenance and reactive maintenance.

Although most frameworks share similar characteristics, each publicsector construction framework has unique properties depending on its particular scope, geographical area and financial value. Nonetheless, in recent years fiscal constraints imposed by central government have encouraged local authorities to form into regional frameworks to share resources. Such shared arrangements are available to local authorities, schools, academies and other public 
bodies within a regional or national area (Department of Education, 2019). A further development has been the emergence of 'multi-lot' frameworks where different suppliers can apply for different geographical areas, different project values or a different scope of work. Such multi-supplier, multi-lot arrangements provide examples of stable cluster communities supported through multi-client organisations.

A major attraction to most client organisations who have demands for regular construction services are that only one significant tendering process is required for inclusion into a framework stage. Once selected within a framework, there is a 'call-off' stage which involves a smaller number of suppliers and hence a simpler 'minicompetition' procedure. Use of these two-stage tendering methods can substantially reduce the extent and overall number of procurements that clients and suppliers would otherwise be involved with. Often a certain amount of standard documentation is included with the framework stage and this remains applicable for the four-year duration. This translates into less complex tendering exercises at the mini-competition call-off stage, reducing cost and timescales for clients.

For suppliers, the opportunities for success are increased as frameworks often engage with a lower number of suppliers than with open tender arrangements. Frameworks that combine the use of standard documentation and fewer, but more active, suppliers reduce transaction costs overall by a significant amount (Lam and Gale, 2014b).
More sophisticated frameworks provide substantial terms for governing call-off arrangement contracts that may be awarded during the life of an agreement. Apart from terms expected in standard forms of construction contract, additional clauses dealing with overall levels of performance, key performance indicators, early contractor involvement and similar, are included to ensure that all suppliers and clients are aware of the drivers behind each framework (Wondimu, et al, 2020). Most construction frameworks are therefore specifically designed to be used with standard forms of contract such as GC/Works, JCT and NEC versions.

\subsection{Desired project outcomes}

In the UK central government advises that public-sector clients should concentrate on required performance outcomes to determine project success (Cabinet Office, 2011). Research into highways maintenance projects allowed Lam and Gale (2014a) to identify five critical success factors that measured the extent of success of public sector projects. These factors can be grouped into three project outcomes:

- Time: start on time (ratio of days late starting against contract period) and finish on time (ratio of days finished late against contract period).

- Cost: accuracy of payment (interim payments certified to within $5 \%$ of contractor's application).

- Quality: right first time (projects completed with minimal remedial works and maximal pass 
percentage of health and safety inspections).

Over time, progressive reductions in budget support from central government have encouraged local authorities to seek ways to ensure value for money from their capital and revenue budgets. The need for cost reduction and quality improvement is reiterated further by the Audit Commission (2011). To increase value from construction, public authorities are encouraged to recognise value, set against criteria upon which suppliers' proposals will be judged. These can include topics such as sustainable value and lifecycle costs.

In addition to time, cost and quality, sustainable performance of government assets through effective procurement of construction services is also a significant objective of the UK Government's Construction 2025 report (BIS, 2013). The Department of Environment, Food \& Rural Affairs (2015) adds that stimulating economic growth, maximising wellbeing and protecting the environment are also the objectives of the 2010 to 2015 Government Policy: Sustainable Development, and that all departments are responsible for making sure that their own policies and activities contribute toward these. Examples of sustainable measures are the reduction of carbon emissions and water consumption, the minimisation of waste to landfill, and engagement with stakeholders to improve environmental performance in accordance with targets from government policy, as stated by the Cabinet Office (2020a).
These findings coincide with the sustainability strategy and project outcome indicators suggested by Local Government Association (2020) for ensuring effective construction frameworks used in the public sector. Such sustainable project outcomes, recognised by Sonnichsen, and Clement (2020) are:

\section{Reduction of waste to landfill.}

Energy and carbon reduction.

Environmental impact \& wildlife protection.

Capital, revenue and whole life costs.

Health, safety, wellbeing and elimination of accidents.

Use of these key performance indicators (KPI) for performance monitoring.

The demands upon suppliers to achieve such outcomes are significant and require an approach from the client's perspective arising from closer and stronger relationships through long-term arrangements. The greater depth of understanding between all participants requires a higher level of commitment to the client and in so doing can be identified through the following indicative attributes (Estate Management Office, 2014):

Being fair, responsive and courteous with the delivery of quality services. Being positive and providing a service which meets customers' requirements.

Aspiring to 'right first time'. Responding effectively to customers' complaints and using customer 
feedback to identify continuous

improvement.

The summation of outcomes and operationalised indicators is shown in Table 1.

Table 1: Project outcomes and indicators

\begin{tabular}{|c|c|}
\hline $\begin{array}{l}\text { Project outcome } \\
\text { (used for the t-test and } \\
\text { regression analysis) }\end{array}$ & Operationalised indicators \\
\hline \multirow[t]{3}{*}{ Time } & framework projects keep to agreed programmes \\
\hline & framework projects start on time \\
\hline & framework projects complete on time \\
\hline \multirow[t]{2}{*}{ Cost } & framework projects keep to agreed budgets \\
\hline & framework projects minimise life cycle costs \\
\hline Quality & $\begin{array}{l}\text { framework projects deliver a functional product with } \\
\text { minimal defects }\end{array}$ \\
\hline \multirow[t]{3}{*}{ Sustainability } & $\begin{array}{l}\text { framework projects encourage innovations leading to cost } \\
\text { and time savings as a proportion of project totals } \\
\text { (economic sustainability) }\end{array}$ \\
\hline & $\begin{array}{l}\text { framework project projects offer higher standards of } \\
\text { health and safety (wellbeing and social sustainability) }\end{array}$ \\
\hline & $\begin{array}{l}\text { framework projects offer environmental improvements in } \\
\text { terms of reduction in carbon emission, water } \\
\text { consumption and waste (environmental sustainability) }\end{array}$ \\
\hline \multirow[t]{4}{*}{$\begin{array}{l}\text { Closer relationships with } \\
\text { clients }\end{array}$} & $\begin{array}{l}\text { participants within a framework are fair, responsive and } \\
\text { courteous }\end{array}$ \\
\hline & suppliers are more positive in providing services \\
\hline & suppliers usually get things right first time \\
\hline & suppliers respond effectively to client's requests \\
\hline
\end{tabular}

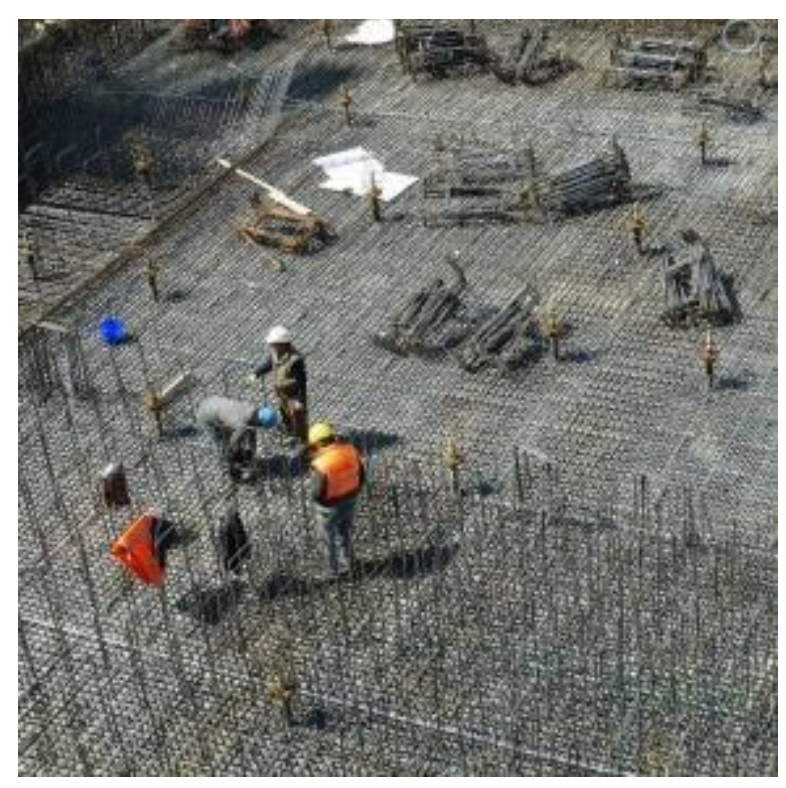




\section{Performance drivers: a literature review}

\subsection{Theory of job performance}

The theory of job performance as proposed by Masa'deh et. al. (2016) suggests two components, namely, task performance and contextual performance. The former refers to task proficiency, i.e., skills, competence/experience, and expertise required to perform one's own tasks effectively. The latter refers to interpersonal skills (communication and coordination) and motivation (initiative and teamwork within an organisational setting) to maintain good working relationships and help others perform their tasks. These two aspects are therefore considered to be critical for personal selection, and task and contextual performance of the project staff and their organisation are therefore important to drive project outcomes.

Within the context of appointments of construction consultants, Lam (2017 and 2020a) demonstrated, through regression analysis of 60 consultancy cases engaged by the UK university estate offices, that the project outcomes of time, cost, quality, sustainability and client relationships were significantly correlated to task and contextual factors driving their performance. In particular the performance factors of project staff, execution approach, as well as collaboration and trust, were considered prominent. These results enlighten the effects of task and contextual performance factors on the project outcomes of building and construction projects, which forms a good basis for assessing their impact on the framework supplier's (contractor) performance.

\subsection{Task performance factors}

In line with the theory of job performance, Morledge et al. (2021) spell out that technical skills, management expertise and financial resources have long been recognised as critical performance factors of contractors for project success. In operational practice these factors are driven through:

capability and structure of the firm

competence of the firm

project staff

\section{executive approach}

Capability refers to the expertise and structure of a supplier. This is measured by the overall experience of firms with projects of a similar function, as well as the structure of a firm in relation to its resources of sufficient staff at senior and operative levels, strength of financial systems, facilities, assets and quality control systems to meet the demands of projects.

Apart from these measures, Xiao and Proverbs (2002a; 2002b; 2002c) found that a contractor's performance (time, cost and quality) is positively 
correlated with commitment towards long-term employment, as demonstrated through investigation of Japanese contractors. A commitment towards long-term employment from employers resulted in stronger allegiance from staff due to investment with training and improved quality systems. The resultant higher skilled workforce achieves higher productivity levels.

Competence refers to the supplier company's past performance in relation to its ability to generate, select and implement or execute projects skillfully through the generation of ideas, resource management and organisation of project implementation. Examples of successful competence and performance are considered to be the best predictor of future behaviour performance according to the theory of selection psychology (Ling, 2000). According to Kashiwagi (2004), clients are likely to achieve a successful project if those suppliers that can demonstrate previous competences are selected.

Project staff refers to the relevant expertise and experience of the personnel directly engaged in the project, particularly the construction team leader and other nominated key staff. It is important that the construction team leader should promote harmonious relationships through mutual respect and trust with sub-contractors and other suppliers. Yeung et al. (2008) add that management commitment, expressed as a percentage of meetings attended by project managers and directors (and thereby showing commitment to the project), is one of the critical factors to aid project success.

Execution approach is about design and management methods employed to meet the client's needs. It is a measure of understanding a client's practical needs in terms of function, operational efficiency, aesthetics, cost and time constraints, and environmental objectives. It is also a reflection of the managerial procedures adopted for communicating with the client and the management of programmes and subcontractors. Atkin and Brook (2021) recognise the positive impact of execution approach for achieving project outcomes of new build and refurbishment projects. How to work around existing occupiers is a particular example relevant to refurbishment projects.

Task performance factors and their measures considered in tender assessment of the procurement phase are summarised in Table 2. 


\begin{tabular}{|c|c|}
\hline \multicolumn{2}{|l|}{$\begin{array}{l}\text { (predictor variable for the } \\
\text { regression analysis) }\end{array}$} \\
\hline \multirow{3}{*}{$\begin{array}{l}\text { Project staff } \\
\text { (relevant expertise \& } \\
\text { experience) }\end{array}$} & $\begin{array}{l}\text { project staff within frameworks commit time and effort } \\
\text { towards positive project outcomes }\end{array}$ \\
\hline & $\begin{array}{l}\text { suppliers provide staff with appropriate qualifications and } \\
\text { experience }\end{array}$ \\
\hline & $\begin{array}{l}\text { project staff within frameworks promote harmonious } \\
\text { relationships with sub-contractors }\end{array}$ \\
\hline \multirow[t]{2}{*}{$\begin{array}{l}\text { Execution approach } \\
\text { (design and management } \\
\text { methods) }\end{array}$} & $\begin{array}{l}\text { suppliers within frameworks provides projects that meet the } \\
\text { overall standards of client's practical needs in terms of price, } \\
\text { quality, time and in accordance with environment } \\
\text { considerations. }\end{array}$ \\
\hline & $\begin{array}{l}\text { frameworks encourage good managerial procedures } \\
\text { (communication with clients; managing the programme and } \\
\text { sub-contractors; working around existing occupiers; } \\
\text { collaboration with other project team members) }\end{array}$ \\
\hline \multirow[t]{2}{*}{$\begin{array}{l}\text { Competence of suppliers } \\
\text { (past performance) }\end{array}$} & $\begin{array}{l}\text { only suppliers with good past performance are included within } \\
\text { frameworks }\end{array}$ \\
\hline & $\begin{array}{l}\text { only suppliers with a record of good health and safety } \\
\text { standards are included within frameworks }\end{array}$ \\
\hline \multirow{5}{*}{$\begin{array}{l}\text { Structure of suppliers / } \\
\text { capability } \\
\text { (overall experience \& } \\
\text { facilities) }\end{array}$} & $\begin{array}{l}\text { frameworks require that senior managers hold relevant } \\
\text { qualifications }\end{array}$ \\
\hline & $\begin{array}{l}\text { frameworks require that suppliers have the relevant technical } \\
\text { abilities }\end{array}$ \\
\hline & frameworks only include suppliers who are financially stable \\
\hline & $\begin{array}{l}\text { frameworks require suppliers to operate quality management } \\
\text { systems }\end{array}$ \\
\hline & $\begin{array}{l}\text { inclusion within a framework provide continuity for the } \\
\text { employment for staff }\end{array}$ \\
\hline
\end{tabular}

\subsection{Contextual performance factors}

Using semi-structured interviews conducted with some of the largest construction clients in the UK (Butcher and Sheehan, 2010) suggested that the following behaviours, attitudes and culture were performance drivers prevalent in the service provided by national contractors:

\section{Behaviours}

- Being open about a company's business strengthens and weaknesses set against their peer group.
- Self-improvement without the need for prompting.

- Focusing on innovation and added values with tangible outputs.

\section{Attitudes}

- Maintaining effective two-way communication.

- Exceeding the client's and stakeholders' expectations.

- Providing consistent communications from staff at all levels.

\section{Culture}

- Providing senior management support through visibility with meetings and discussions for the programme of works. 
- Confirming ownership of the programme through commitment of resources at appropriate times.

- Encouraging mutual levels of trust and respect to all.

- Providing cultural alignment with the client's needs.

- Supporting shared culture of learning and development amongst all suppliers through regular risk-sharing workshops.

- Understanding what each party needs and aligning outcomes to deliver these objectives through shared incentives.

- Providing learning and development opportunities shared among all suppliers and stakeholders.
Contextual performance may also be influenced through the contractual relationships of consultants and suppliers with clients. Standard forms of contract provide the context within which the parties operate. For example, the NEC4 Framework Contract (NEC4, 2017) requires that the parties act in a spirit of mutual trust and co-operation. This has been applied by the courts when ruling on clauses contained within the NEC suite of contracts (Northern Ireland Housing Executive $v$ Healthy Buildings (Ireland) Limited 2014).

Contextual performance factors and their measures are summarised in Table 3.

Table 3: Contextual performance factors

\begin{tabular}{|l|l|}
\multicolumn{1}{|c|}{$\begin{array}{c}\text { Performance factor } \\
\text { (predictor variable for the } \\
\text { regression analysis) }\end{array}$} \\
\begin{tabular}{|l|l|} 
Conscientious behaviour and \\
attitude
\end{tabular} & $\begin{array}{l}\text { framework participants are open with peers about } \\
\text { strength and weakness }\end{array}$ \\
\cline { 2 - 2 } & $\begin{array}{l}\text { framework participants self-improve without the need for } \\
\text { prompting }\end{array}$ \\
\cline { 2 - 3 } & $\begin{array}{l}\text { framework participants focus on innovations and added } \\
\text { values }\end{array}$ \\
\cline { 2 - 3 } & $\begin{array}{l}\text { framework participants maintain effective two-way } \\
\text { communications }\end{array}$ \\
\cline { 2 - 3 } & $\begin{array}{l}\text { frameworks encourage consistent communication at all } \\
\text { levels of the construction team }\end{array}$ \\
\cline { 2 - 3 } & $\begin{array}{l}\text { frameworks provide timely responses and quick reaction } \\
\text { times }\end{array}$ \\
\hline Culture & $\begin{array}{l}\text { frameworks encourage effective management and } \\
\text { commitment to programme }\end{array}$ \\
\cline { 2 - 3 } & $\begin{array}{l}\text { frameworks provide alignment with the client's culture by } \\
\text { understanding what they want and deliver what they } \\
\text { require }\end{array}$ \\
\cline { 2 - 3 } & $\begin{array}{l}\text { frameworks provide a shared culture of learning and } \\
\text { development amongst all suppliers }\end{array}$ \\
\hline Trust and collaboration & $\begin{array}{l}\text { - frameworks encourage collaborative behaviours through } \\
\text { high levels of trust and respect to the client }\end{array}$ \\
\hline
\end{tabular}




\subsection{Client's organisational factors}

A strong link between organisational culture and productivity/performance is well established, being supported through a substantial number of studies from the field of sociopsychological investigation into teams and groups (Zhang and Liu, 2006). Other areas of behavioural research identify progressive stratification of interaction between group culture, group behaviour and group performance (Tellis et al., 2009; Oyewobi, et al., 2016). However, an examination of groups involved with construction projects by Walker (2011) concluded that 'research on the impact of culture on organisational performance is mixed'. Although Walker cited examples from a range across the cultural spectrum, he could not reach any definitive conclusions. On balance the published literature, while not providing conclusive evidence between culture and performance, does support organisational behaviours as a driver for group performance.

Within the construction industry, the use of financial 'pain or gain' monetary payments to encourage increased output set against outturn productivity targets has historically been a popular method of incentivisation. Bresnen and Marshall (2000) proposed that operational financial incentives coupled with advanced contracting methods could improve both commitment and motivation within projects.

A case study examined by Lam and Gale (2015) found that incentive mechanisms could be linked to key performance indicators (KPIs) enabling focus upon the client's outcomes through financial incentives. The resultant pain or gain could be a pure financial transaction (monetary bonus or deduction) based upon a graduated scale of results, or an improved chance to be either selected or deselected for a future project. Suppliers preferred the chance of winning further work rather than individual project bonuses, and the framework agreement reflected this choice.

Lam (2020b) examined which KPIs and drivers should be applied at the construction phase to monitor and drive project outcomes in sustainable design and construction for development. The results demonstrated that economic, functional, social and environmental sustainability KPIs are relevant for monitoring the performance of construction frameworks, and these could be driven by related task and contextual performance factors. The significant impact of success criteria and KPIs upon project delivery was also identified by Oyewobi, et al. (2016) through regression analysis.

Although most KPIs within construction measure the performance of suppliers, Butcher and Sheehan (2010) recognised the role clients play. Clear leadership and outcomes together with commitment and inclusion are qualities of 'good clients' according to the Cabinet Office (2020b). Such qualities are reinforced through longer relationships afforded by framework procurement methods. Both parties feel a part of a collaborative team and this reinforces leadership offered by a client. 
The economics of procurement also have a role to play within the mix of clients and suppliers to a framework. Most frameworks seek to reduce the number of suppliers, thereby enabling a closer relationship and greater certainty of price. A counter to this argument is concern from some clients that there is less competition and therefore potentially higher prices. A further concern may be whether suppliers have the capacity to undertake extensive programmes of work. It is therefore essential that a client carefully considers the appropriate number of suppliers at the procurement stage to encourage healthy competition while maintaining quality of service or work (Lam and Gale, 2014a).

Client's organisational performance factors and their measures are summarised in Table 4. These factors should be applied at the pre-contract procurement and the post-contract construction phases to encourage and motivate good performance from the suppliers.

Table 4: Client's organisational performance factors

\begin{tabular}{|c|c|}
\hline $\begin{array}{l}\text { Performance factor } \\
\text { (predictor variable for the } \\
\text { regression analysis) }\end{array}$ & Operationalised Measure \\
\hline \multirow[t]{5}{*}{ Procurement approach } & $\begin{array}{l}\text { it is better to have more suppliers in the framework } \\
\text { rather than fewer due to competition }\end{array}$ \\
\hline & $\begin{array}{l}\text { frameworks that use pre-priced schedule of rates provide } \\
\text { a better share of risks between client and supplier }\end{array}$ \\
\hline & $\begin{array}{l}\text { frameworks do improve performance through standard } \\
\text { documentation in clear and concise language with clear } \\
\text { evaluation procedures }\end{array}$ \\
\hline & $\begin{array}{l}\text { frameworks establish stronger relationships between } \\
\text { suppliers and clients due to longer arrangements }\end{array}$ \\
\hline & $\begin{array}{l}\text { an extension to the framework is an incentive to gain } \\
\text { continued good performance from suppliers }\end{array}$ \\
\hline Communication & $\begin{array}{l}\text { effective communication is achieved with a framework } \\
\text { supplier due to stronger and longer relationships }\end{array}$ \\
\hline \multirow[t]{2}{*}{ Incentives } & $\begin{array}{l}\text { monitoring performance within a framework encourages } \\
\text { better outcomes and the ability to win further projects }\end{array}$ \\
\hline & $\begin{array}{l}\text { publication of performance results creates a culture of } \\
\text { driving performance }\end{array}$ \\
\hline \multirow[t]{3}{*}{ Performance monitoring } & $\begin{array}{l}\text { use of specific key performance indicators concentrates } \\
\text { performance upon the client's outcomes }\end{array}$ \\
\hline & $\begin{array}{l}\text { carry out monthly formal and informal site inspections to } \\
\text { measure performance is worthwhile and effective }\end{array}$ \\
\hline & $\begin{array}{l}\text { applying incentive payment to actual performance criteria } \\
\text { is worthwhile and effective }\end{array}$ \\
\hline Leadership & $\begin{array}{l}\text { frameworks encourage strong leadership and effective } \\
\text { performance from a supplier }\end{array}$ \\
\hline
\end{tabular}




\section{The research}

\subsection{Research Methods}

The research methods for this study comprised the following five stages:

Literature review (discussed in the previous chapter) of performance drivers with reference to job performance and project management theories to construct a pilot survey.

Expert pilot survey conducted with three senior client construction managers having extensive experience in managing construction frameworks within the public sector to determine project outcomes and performance factors and refine the research hypotheses.

Quantitative independent-samples ttest conducted in order to verify $\mathrm{RH} 1$, using 70 sets of data on project outcomes collated from a questionnaire survey of front-line project managers involved with building construction and civil engineering frameworks.

Quantitative hierarchical regression analysis conducted to address $\mathrm{RH} 2$ and $\mathrm{RH} 3$, also based on the 70 data sets of performance influences collated from a questionnaire survey.

Qualitative multiple-case study including structured interviews conducted on eight typical building constructions and five civil engineering framework projects in order to provide further explanation and evidential support for the casual relationships ( $\mathrm{RH} 2$ and $\mathrm{RH} 3$ ) as revealed by the quantitative regression study.

The pilot study included the circulation of a questionnaire to a limited number of practitioners with experience of construction projects in the fields of building and civil engineering and also knowledge of discrete (standalone) and framework procurement methods.

\subsection{Hypotheses}

Review of the pilot study following responses from the practitioners then identified and confirmed the following hypotheses about the construction project outcomes, as matters for investigation:

time savings (POT)
cost savings (POC)
quality (POQ)
sustainability (POS)
relationships (POR)

Feedback from practitioners contained within the pilot study questionnaire also allowed the following research hypotheses $(\mathrm{RH})$ to be developed:

RH1: Building construction and civil engineering frameworks significantly improved project outcomes.

Figure 1: Hypothetical Performance Improvement Model for Public-Sector Construction Frameworks 


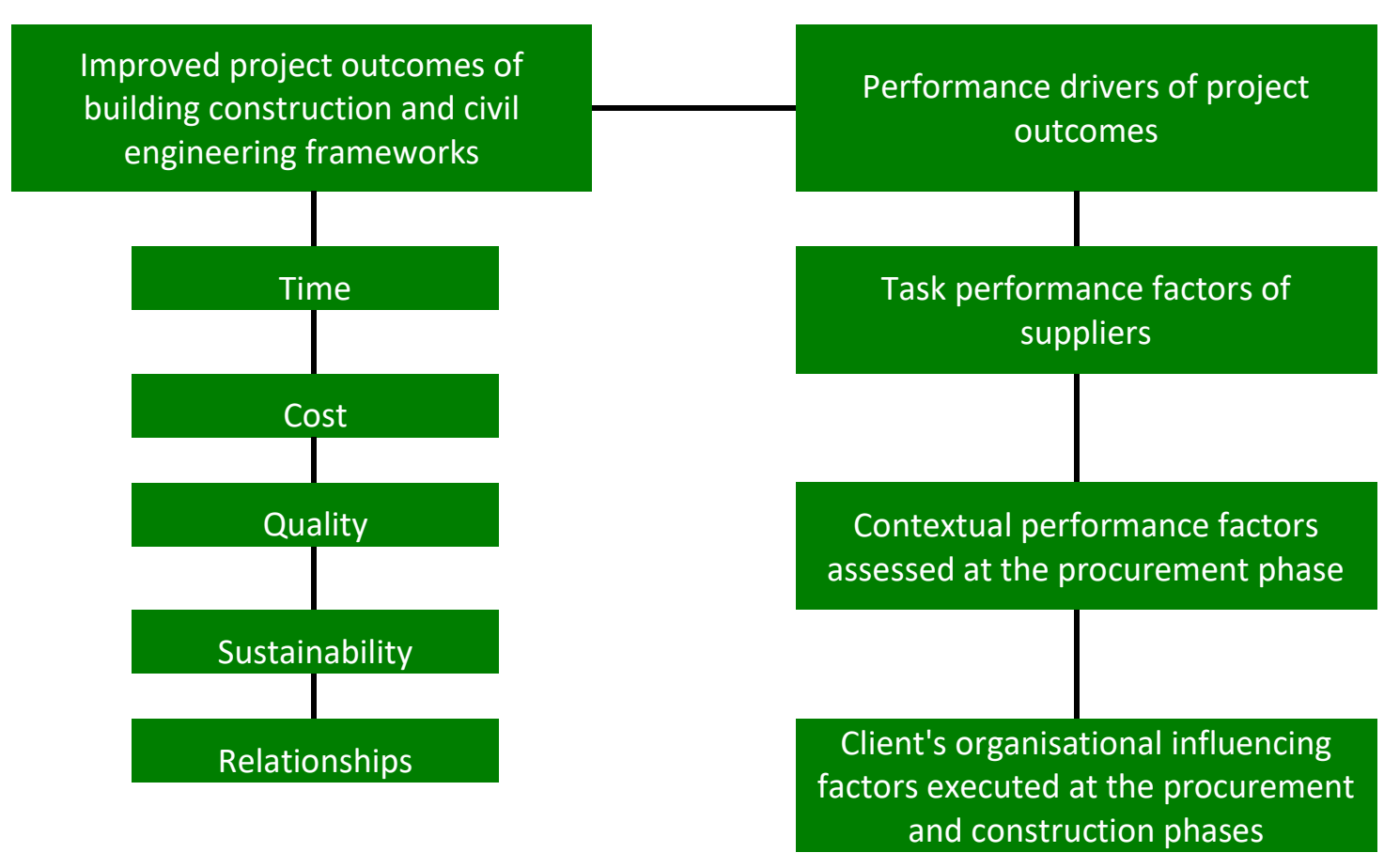

RH2: Individual project outcomes (POT, POC, POQ, POS and POR) positively correlated to the level of supplier's task and contextual performance factors (TCF) assessed at the procurement (tender) phase.

RH3: Individual project outcomes (POT, POC, POQ, POS and POR) positively correlated to the level of client's organisational factors (COF) executed at the procurement and construction phases.

\subsection{Theoretical model \& questionnaire}

On the basis of these hypotheses, a theoretical performance-driving model for construction frameworks (Figure 1) was constructed which simulated the impact of performance drivers (identified by the right column) on project outcomes (identified by the left column), as hypothesised by $\mathrm{RH} 2$ and RH3.

The model established a baseline upon which a detailed questionnaire was then constructed to explore project outcomes in greater detail through engagement with a larger sample of practitioners. This provided data from questionnaires (for t-test and hierarchical regression analysis) and also qualitative evidence gathered from eight semi-structured interviews (for multiple-case studies). The data for the questionnaires was collected between March 2019 and February 2020, spread across the geographical area of England, within the UK.

Fellows and Liu (2015) suggest that regression is appropriate when investigating relationships between the predicted outcome variable (POT, POC, POQ, POS or POR) and the predictor variables (TPF and COF drivers) within the field of construction management. Hierarchical regression can also assess the relative contribution of each block of predictors (Pallant, 2020), namely 
task performance, contextual performance and a client's organisational factors. The use of multiple case studies to gain rich data is advocated by Yin (2018) as a method for allowing collection of reliable evidence to produce reliable results.

The questionnaire was sent to two significant areas of public-sector organisations in England that regularly require construction services: infrastructure offices of all public government authorities and highway authorities listed by the Local Government Association (LGA), and estate offices of public universities and colleges. At the time of issue of the questionnaire in 2019, there were 343 local authorities (unitary, county and district councils) and 111 universities and university colleges within the geographical area of England.

The number of responses received for the survey was 70 , representing $15.4 \%$ of the total possible maximum (454).

Discussions with practitioners undertaken at the pilot study stage indicated that at least $50 \%$ of authorities contacted had no need nor use of frameworks as their capital and revenue programmes did not warrant multiple projects. Under these circumstances a return of 70 , comprising 35 for building construction frameworks and 35 for civil engineering frameworks, provided a balanced sample for the t-test and regression analysis and the best available anticipated response for the sector.

In the field of construction management, Fellows and Liu (2015) confirmed that small samples scaled to a larger population are less reliable than large samples due to the proportionality of differences becoming a wider variance. The boundary between large sample size and small sample size is dependent upon the amount of variability of the population, but as this research lies within a reasonably controlled environment (regulated by procurement legislation) and involves construction professionals (regulated by professional standards) a sample size of more than 30 is considered sufficient to conduct a t-test. Generalising the regression analysis results also requires having a sufficient number of cases. Coakes and Steed (2007) stipulate that a minimum requirement is at least six times the number of predictor variables. As this research generated 12 possible predictor variables from the literature review (task, contextual and client's organisational factors), the minimum number of cases required would be 72. A sample of 70 datasets used by this research appears sufficient to meet these standards.

Participants to the questionnaire were asked questions related to project outcomes and performance influencing factors (Tables 1 to 4). These were placed against a context of recently completed or substantially completed framework and nonframework projects. The views were rated against levels of performance and associating influencing factors, using a Likert scale between 1 (strongly disagree) and 7 (strongly agree). The questionnaire sought to find:

The average performance level of individual project outcomes achieved 
by a chosen framework project and a similar traditional discreet project.

The level of supplier's task and contextual performance factors revealed in the tender assessment at the procurement phase, covering prequalification, interview and tender evaluation.

The level of client's organisational factors that the client adopted to motivate and monitore the supplier's performance at the procurement and construction phases.

For the qualitative multiple-case study and interviews, typical case organisations were selected to provide a contextual balance. These organisations were chosen according to similarities with asset management responsibilities, types of services and works, procurement routes and procedures, and where the organisation offered performance monitoring and incentives. Within each organisation, a representative building construction or civil engineering framework project was chosen in terms of size, value and scope of works to assist with explanation of causal relationships between project outcomes and the performance drivers identified.

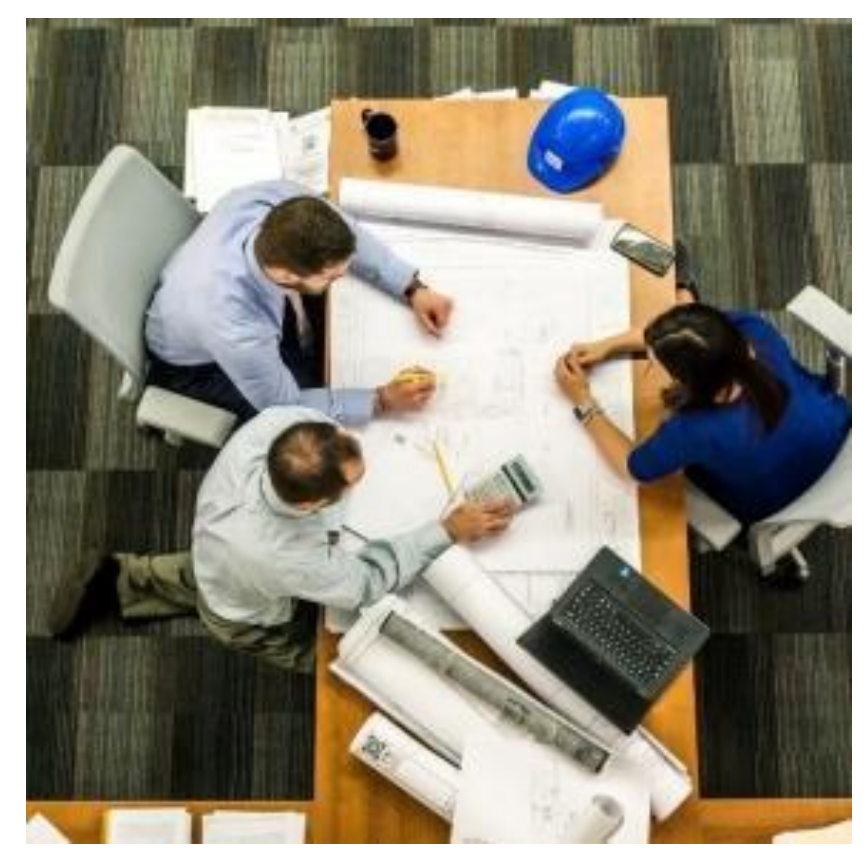




\section{Results and discussion}

\subsection{Independent-samples t- test and project outcomes}

Data from the five project outcomes (POT, POC, POQ, POS and POR) were subjected to independent-sample ttests, with the results shown in Table 5 and 6 . As the sig. (two-tailed) $p$ value was less than 0.0005 in each project outcome (Table 6 ), the results generalise that the performance of time, cost, quality, sustainability and closer relationships achieved by the framework projects were all significantly higher than that of the traditional discrete projects. It can be concluded from these results that Hypothesis RH 1 is validated.

The performance mean scores of the 70 framework projects were:

POT $=5.85 / 7=84 \%$;

$P O C=5.10 / 7$ = 73\%;

$P O Q=5.20 / 7=74 \%$;

$\mathrm{POS}=4.98 / 7=71 \%$;

POR $=5.61 / 7=80 \%$.

In relation to the magnitude of the difference in the mean performance, an eta squared $\left(\mathrm{n}^{2}\right)$ statistic is used to examine the effect size. Eta squared is a different effect size statistic, ranging from 0 to 1 , representing the proportion of variance in the independent variable that is explained by the independent (group) variable. According to Pallant (2020), 0.01 infers a small effect, 0.06 represents a moderate effect and 0.14 represents a large effect. Conclusions from the results are that building construction and civil engineering frameworks can significantly improve the project outcomes of time, cost, quality, and sustainability with a small to moderate effect. For project outcome of closer relationships, the range of improvement is a moderate to large effect (Table 5).

These findings provide empirical evidence to the assertions made by Constructing Excellence (2019b) that construction frameworks, as a primary aim, seek to provide closer, stronger relationships through longer term arrangements. The effect of this relationship provides greater understanding between all participants and a higher level of commitment from the whole supplier chain, thereby increasing value. 
Table 5: Comparing the project outcomes of construction frameworks and traditional discrete projects: Means and eta squared $\left(\mathrm{n}^{2}\right)$ statistic

\begin{tabular}{|c|c|c|c|}
\hline Project Group & Number & $\begin{array}{l}\text { Group Statistics } \\
\text { Mean (out of } 7 \text { ) }\end{array}$ & $\begin{array}{l}\text { Magnitude of } \\
\text { Difference in the } \\
\text { mean performance } \\
\text { (eta squared }\left(\mathrm{n}^{2} \text { ) }\right. \\
\text { statistic }\end{array}$ \\
\hline $\begin{array}{l}\text { Project Outcome of Time: } \\
\text { Framework projects } \\
\text { Traditional discrete projects }\end{array}$ & $\begin{array}{l}70 \\
70\end{array}$ & $\begin{array}{l}5.8477 \\
5.1526\end{array}$ & $\begin{array}{l}0.0329 \\
\text { (small to moderate } \\
\text { effect) }\end{array}$ \\
\hline $\begin{array}{l}\text { Project Outcome of Cost: } \\
\text { Framework projects } \\
\text { Traditional discrete projects }\end{array}$ & $\begin{array}{l}70 \\
70\end{array}$ & $\begin{array}{l}5.1000 \\
4.4857\end{array}$ & $\begin{array}{l}0.0181 \\
\text { (small to moderate } \\
\text { effect) }\end{array}$ \\
\hline $\begin{array}{l}\text { Project Outcome of Quality: } \\
\text { Framework projects } \\
\text { Traditional discrete projects }\end{array}$ & $\begin{array}{l}70 \\
70\end{array}$ & $\begin{array}{l}5.2000 \\
4.4857\end{array}$ & $\begin{array}{l}0.0151 \\
\text { (small to moderate } \\
\text { effect) }\end{array}$ \\
\hline $\begin{array}{l}\text { Project Outcome of } \\
\text { Sustainability: } \\
\text { Framework projects } \\
\text { Traditional discrete projects }\end{array}$ & $\begin{array}{l}70 \\
70\end{array}$ & $\begin{array}{l}4.9817 \\
4.2934\end{array}$ & $\begin{array}{l}0.0336 \\
\text { (small to moderate } \\
\text { effect) }\end{array}$ \\
\hline $\begin{array}{l}\text { Project Outcome of Closer } \\
\text { Relationships } \\
\text { Framework projects } \\
\text { Traditional discrete projects }\end{array}$ & $\begin{array}{l}70 \\
70\end{array}$ & $\begin{array}{l}5.6143 \\
4.7643\end{array}$ & $\begin{array}{l}0.0671 \\
\text { (moderate to large } \\
\text { effect) }\end{array}$ \\
\hline
\end{tabular}

Table 6: Comparing the project outcomes of construction framework and traditional discrete projects: Significance of the mean differences

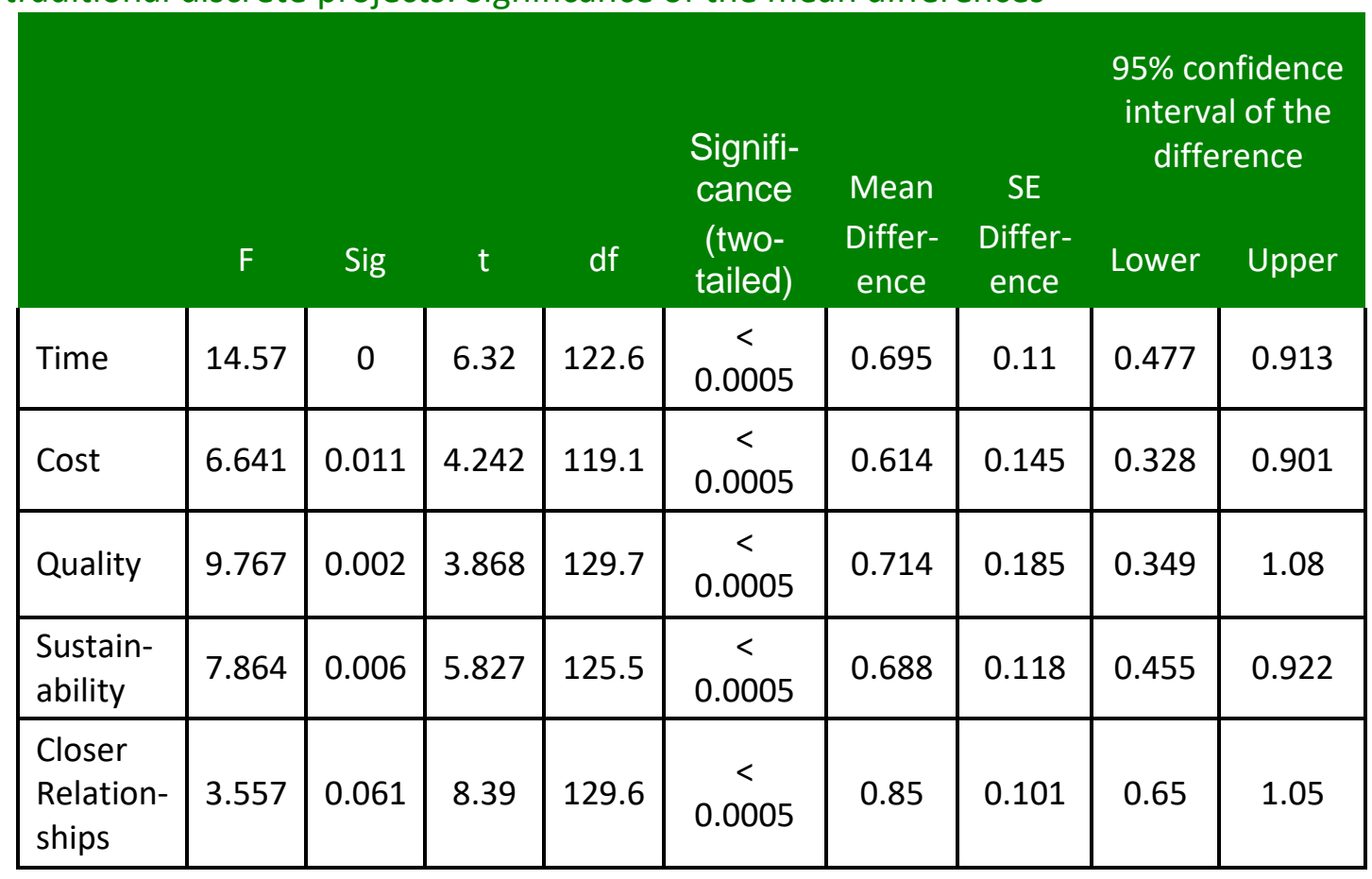




\subsection{Hierarchical regression analysis and performance drivers}

Using hierarchical regression analysis, data from the quantitative questionnaire was used to identify significant performance factors that influence the project outcomes, as described by Hypotheses $\mathrm{RH} 2$ and $\mathrm{RH} 3$. The results are summarised as below and shown in Table 7.

\section{Project outcome of time}

Project outcome of time (POT) had a significant overall correlation and significant individual relationships with the supplier's 'conscious behaviour and attitude' (CON) and 'trust and collaboration' (CFW), as well as the client's 'incentives' (ICE) and 'performance monitoring' (MON), with the causal relationship developed as follows:

POT $=0.115+(0.381 \mathrm{CON}+0.685 \mathrm{CFW})$ $+(0.303 \mathrm{ICE}+0.245 \mathrm{MON})$

\section{Project outcome of cost}

Project outcome of cost (POC) had a significant overall correlation and significant individual relationships with the supplier's 'project staff' (PST), 'competence' (COP) and 'culture' (CUL), with the causal relationship developed as follows:

$\mathrm{POC}=-0.435+(0.941 \mathrm{PST}+0.146 \mathrm{COP})$ $+(0.261$ CUL $)$
Project outcome of quality

Project outcome of quality (POQ) had a significant overall correlation and significant individual relationships with the supplier's 'culture' (CUL) and the client's 'procurement approach' (PRO), with the causal relationship developed as follows:

$P O Q=0.03+(0.715 C U L)+(1.139 P R O)$

Project outcome of sustainability

Project outcome of sustainability (POS) had a significant overall correlation and significant individual relationships with the supplier's 'culture' (CUL) and the client's 'procurement approach' (PRO), with the causal relationship developed as follows:

POS $=0.026+(0.517 C U L)+$ (0.802PRO)

Project outcome of closer relationships of parties (POR) Project outcome of closer relationships (POR) had a significant overall correlation and significant individual relationships with to the supplier's 'structure' (SOS) and 'trust and collaboration' (CWF) as well as the client's effective 'communication' (COM) with a framework supplier, with the causal relationship developed as follows:

POR $=1.404+(0.205$ SOS $)+$ $(0.740$ CFW $)+(0.422$ COM $)$ 
Table 7: Hierarchical regression analysis of performance outcomes

\begin{tabular}{|c|c|c|c|c|c|c|}
\hline $\begin{array}{l}\text { Project } \\
\text { Outcome }\end{array}$ & $\begin{array}{c}\text { Performance } \\
\text { factor }\end{array}$ & $s r^{2}$ & $p$-value & $\begin{array}{c}\text { Adjusted } \\
\mathrm{R}^{2}\end{array}$ & $\begin{array}{c}\mathrm{R}^{2} \text { Change } \\
\text { (Sig. F Change) }\end{array}$ & $\begin{array}{l}\text { ANOVA } \\
\text { Sig. }\end{array}$ \\
\hline POT & $\begin{array}{l}\text { CON } \\
\text { CFW } \\
\text { ICE } \\
\text { MON }\end{array}$ & $\begin{array}{l}0.040 \\
0.029 \\
0.036 \\
0.024\end{array}$ & $\begin{array}{l}0.002 \\
0.009 \\
0.003 \\
0.015\end{array}$ & 0.731 & $\begin{array}{l}\text { CON \& CFW: } \\
0.673 \text { (<0.0005) } \\
\text { ICE \& MON: } \\
0.074(<0.0005)\end{array}$ & $<0.0005$ \\
\hline POC & $\begin{array}{l}\text { PST } \\
\text { COP } \\
\text { CUL }\end{array}$ & $\begin{array}{l}0.232 \\
0.023 \\
0.024\end{array}$ & $\begin{array}{l}<0.0005 \\
0.037 \\
0.037\end{array}$ & 0.643 & $\begin{array}{l}\text { PST \& COP: } \\
0.635(<0.0005) \\
\text { CUL: } 0.024(0.037)\end{array}$ & $<0.0005$ \\
\hline $\mathrm{POQ}$ & $\begin{array}{l}\text { CUL } \\
\text { PRO }\end{array}$ & $\begin{array}{l}0.213 \\
0.155\end{array}$ & $\begin{array}{l}<0.0005 \\
<0.0005\end{array}$ & 0.376 & $\begin{array}{l}\text { CUL: } 0.239(<0.0005) \\
\text { PRO: } 0.155(<0.0005)\end{array}$ & $<0.0005$ \\
\hline POS & $\begin{array}{l}\text { CUL } \\
\text { PRO }\end{array}$ & $\begin{array}{l}0.261 \\
0.179\end{array}$ & $\begin{array}{l}<0.0005 \\
<0.0005\end{array}$ & 0.454 & $\begin{array}{l}\text { CUL: } 0.290(<0.0005) \\
\text { PRO: } 0.179(<0.0005)\end{array}$ & $<0.0005$ \\
\hline POR & $\begin{array}{l}\text { SOS } \\
\text { CWF } \\
\text { COM }\end{array}$ & $\begin{array}{l}0.036 \\
0.141 \\
0.422\end{array}$ & $\begin{array}{l}0.005 \\
<0.0005 \\
<0.0005\end{array}$ & 0.705 & $\begin{array}{l}\text { SOS: } 0.032(<0.0005) \\
\text { CWF: } 0.299(<0.0005) \\
\text { COM: } 0.098(<0.0005)\end{array}$ & $<0.0005$ \\
\hline $\begin{array}{l}\text { Notes: } \\
\text { Project ou } \\
\text { relationshi } \\
\text { Task perfo } \\
\text { suppliers) } \\
\text { Contextua } \\
\text { collaborat } \\
\text { Client's or } \\
\text { (procurem } \\
\text { sr': relativ } \\
\text { P-value: in } \\
\text { value }<0.0 \\
\text { Adjusted } R \\
\text { Adjusted R } \\
\mathrm{R}^{2} \text { Change: }\end{array}$ & $\begin{array}{l}\text { ips with clients } \\
\text { rmance block } \\
\text { I performance } \\
\text { ion), CUL (cult } \\
\text { ganisational fa } \\
\text { ent approach) } \\
\text { e contribution } \\
\text { dividual relatic } \\
5 \text { means signif } \\
?^{2} \text { : overall corr } \\
?^{2} \text { around } 0.4 \text { o } \\
\text { relative contr }\end{array}$ & $\begin{array}{l}\text { (POR) } \\
\text { factors: } \\
\text { block fac } \\
\text { ure) } \\
\text { ctors blo } \\
\text {, COM (c } \\
\text { of indivi } \\
\text { onships b } \\
\text { icant rel } \\
\text { elation b } \\
\text { r ANOVA } \\
\text { ibution o }\end{array}$ & $\begin{array}{l}\text { (project } \\
\text { s: CON (c } \\
\text { ICE (ince } \\
\text { municati } \\
\text { I perform } \\
\text { veen the } \\
\text { nship. } \\
\text { een proj } \\
<0.05 \mathrm{n} \\
\text { dividual }\end{array}$ & $\begin{array}{l}\mathrm{ff}) \text {, COP } \\
\text { scious b } \\
\text { ves), MO } \\
\text { with a fr } \\
\text { ice facto } \\
\text { oject out } \\
\text { outcom } \\
\text { fors signif } \\
\text { formanc }\end{array}$ & $\begin{array}{l}\text { mpetence), SOS (struc } \\
\text { aviour \& attitude), CFV } \\
\text { (performance monitori } \\
\text { hework supplier) } \\
\text { to the overall correlatic } \\
\text { me and performance } \\
\text { ind all performance fac } \\
\text { int correlation. } \\
\text { olocks to the Adjusted }\end{array}$ & $\begin{array}{l}\text { ure of } \\
\text { (trust \& } \\
\text { ng), PRO } \\
\text { tors; } \\
\text { tetors; p- }\end{array}$ \\
\hline
\end{tabular}

\subsection{Multiple-case study and causal relationships}

Eight case study projects were chosen from public authorities and public universities, which included three building construction framework projects and five civil engineering framework projects. These organisations had already participated in the questionnaire survey and had indicated a willingness to be further involved. Each case study included an in-depth structured qualitative interview with a senior practitioner project manager. All of the project managers chosen had more than 10 years' experience in managing frameworks and between 15 to 25 years' experience with construction management. Each interview lasted approximately 45 minutes and comprised structured questions 
focused upon the performance drivers associated with the project chosen for this study. The project manager's responses, along with any supporting documents, were analysed through qualitative content analysis. The results are summarised in Table 8.

Table 8: Performance drivers identified by content analysis of multiple cases

\begin{tabular}{|c|c|}
\hline Project outcome & Performance driver \\
\hline \multirow[t]{2}{*}{ Time } & $\begin{array}{l}\text { Longer and stronger relationships and teamwork; } \\
\text { working as a team to achieve the agreed programme. }\end{array}$ \\
\hline & $\begin{array}{l}\text { Performance monitoring using key performance indicators; } \\
\text { continuity in workload and good reputation }\end{array}$ \\
\hline \multirow[t]{2}{*}{ Cost } & $\begin{array}{l}\text { Staff and company's experience of similar projects within } \\
\text { the longer-term framework for the enhancement of design } \\
\text { and construction programme. }\end{array}$ \\
\hline & $\begin{array}{l}\text { Teamwork and commitment to keep to the agreed budget; } \\
\text { open discussions with the client> }\end{array}$ \\
\hline \multirow[t]{2}{*}{ Quality } & $\begin{array}{l}\text { After doing a number of similar projects, the suppliers } \\
\text { know which areas to look for to reduce defects; } \\
\text { experience sharing with the clients and other suppliers } \\
\text { within the framework; }\end{array}$ \\
\hline & $\begin{array}{l}\text { Constant performance monitoring using key performance } \\
\text { indicators. }\end{array}$ \\
\hline \multirow[t]{2}{*}{ Sustainability } & $\begin{array}{l}\text { Teamwork and discussions with the client; } \\
\text { discussions between the suppliers on a framework for } \\
\text { improvements of future projects. }\end{array}$ \\
\hline & $\begin{array}{l}\text { Longer and stronger relationships within the framework; } \\
\text { use of key performance indicators for monitoring and } \\
\text { selection for future projects. }\end{array}$ \\
\hline \multirow[t]{3}{*}{ Closer relationships } & Having key sub-contractors in the supply team. \\
\hline & Teamwork and respect. \\
\hline & Providing effective responses to client's requests. \\
\hline
\end{tabular}

In the light of the existing research literature, discussed in Chapter 4, these results can be explained as follows:

\section{Project outcomes and client's organisational factors}

Project managers recognised that as longer and stronger relationships are nurtured within a framework, the supplier, the supervisor and the client worked closer together as a team to achieve desired project outcomes. This ensured that framework suppliers were invested in keeping with agreed start and completion times and to maintain the agreed budgets.

Performance monitoring using key performance indicators provided constant reminders to ensure that project outcomes of time, cost, quality, sustainability and closer relationships are behaviours accepted by the team. Respondents identified that frameworks provided higher levels of certainty and continuity in workload, where suppliers had to perform well in order to be selected 
for future projects and hence to gain good a reputation. These provided strong incentives in driving performance for all project outcomes.

Among the client's organisational factors, 'incentives' and 'performance monitoring' were found by the regression analysis to be significant in influencing project outcome of time. These included the use of framework contractual control measures for performance improvements by allowing performing suppliers to gain a better chance to be selected for further projects. Such contractual measures are supported by KPIs from site inspections and publication of performance results. The contract based KPIs were found to be very effective performance measures for control of time for civil engineering frameworks by Lam and Gale (2015). Bresnen and Marshall (2000) and Morledge et al. (2021) also suggested, but with discrete projects, that financial incentives can improve both commitment and motivation, and hence project outcomes.

'Leadership' is one of the client's organisational factors and frameworks are expected to encourage strong leadership leading to effective performance from a supplier. However, this was not identified as a significant performance driver across all project outcomes by the regression analysis. Tolerance values from this factor in the regression analysis were all around 0.18 , which is quite close to 0.1 (indicating multiple correlation with other variables / multicollinearity is high), suggesting that its effect was masked by other influencing factors, in particular, incentive and performance monitoring which involved an input of leadership. Nonetheless, leadership and ownership are encouraged through the operation of a framework.

Project outcomes and task performance factors

Respondents suggested that regular meetings and open discussions held between clients and suppliers assisted with agreeing cost variations and the final account. With larger value programmes of work the suppliers also offered advice on design improvement, planning and sequencing of construction methods and reductions in life cycle costs, based upon their experience with successes of similar projects (Bleda and Chicot, 2020).

Among the task performance factors, the regression analysis showed the most significant predictor was 'project staff'. Yeung et al. (2008) and Morledge et al. (2021) contended that directly-employed project staff with relevant expertise was one of the critical factors to guarantee project success. This includes skills in budgeting and life cycle cost control, time commitment of project managers and directors towards the project, and enhancement of relationships with the client and the subcontractors.

Such expertise and skills are essential to manage construction frameworks which are often associated with highrisk, high-spend construction and maintenance programmes (Constructing Excellence, 2019a). 'Competence of suppliers' relating to past performance was also identified by the regression analysis to be a significant driver for the project outcome of cost. Knowledge gained from past experiences is particularly 
relevant to design, management and hence the project outcome of cost.

This causal relationship is supported by Xiao and Proverbs (2002a; 2002b; 2002c) and Kashiwagi (2004) who demonstrated that previous success is closely linked to future performance, especially when construction projects are located in constricted areas, i.e., existing highways, transportation and buildings. The ways in which work and services are delivered and communications are handled are becoming increasingly critical (Atkin and Brooks, 2021).

\section{Project outcomes and contextual performance factors}

In relation to the project outcome of closer relationships, respondents felt that as relationships were built over time between clients, supervisors and framework suppliers, this reduced conflicts. The relationships provided a collaborative partnership scenario, with everyone treating each other with respect and courtesy and sharing experience within the team for improving existing and future projects. The closer relationship allowed suppliers to understand client's needs better and this allowed alignment with the client's culture and effective responses to their requests. Moreover, the longer-term arrangements afforded through the framework allowed, in some cases, key sub-contractors to be included as part of the supply team. Constructing Excellence (2019a) argue that it is necessary to create and maintain closer relationships with the whole supply chain (main and sub suppliers).

Among the contextual performance factors, 'trust and collaboration' was found by the regression analysis to be a significant factor influencing the project outcome of closer relationships. With collaborative frameworks, suppliers offer high levels of trust and respect to a client and other stakeholders, which are essential for project success. Yeung et. al. (2008) found trust and respect are critical for solving problems.

All the causal relationships revealed by the case studies explain and support the regression results.

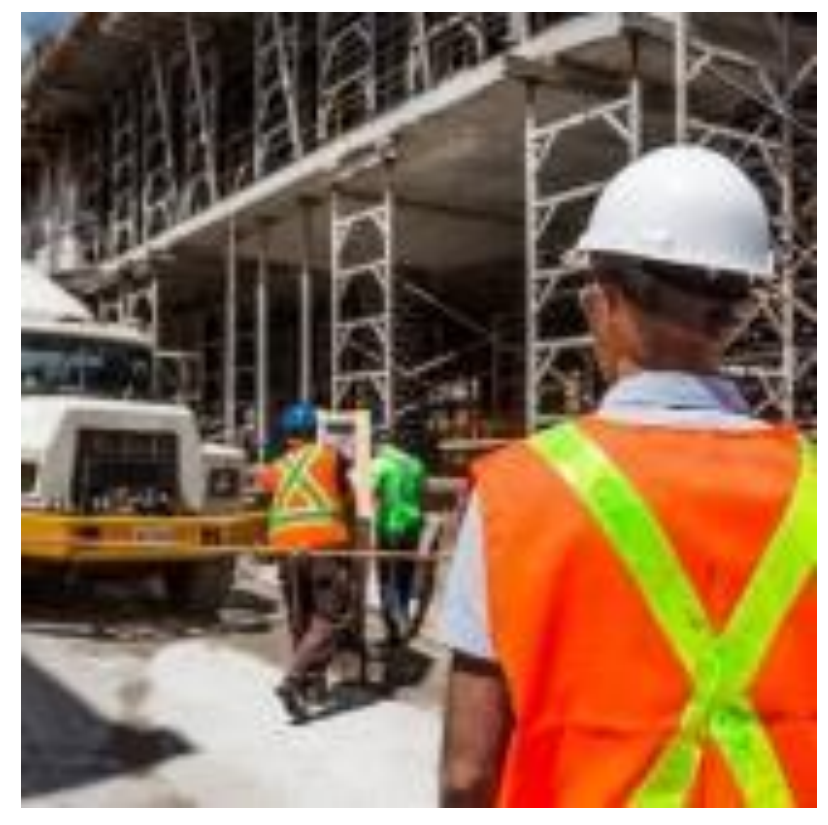




\section{Conclusions and recommendations}

\subsection{Summary of findings}

Results from the independent-samples t-tests confirmed that project outcomes can be significantly improved by the use of construction frameworks, with a 'small to moderate' impact on project time, cost, quality and sustainability and a 'moderate to large' impact on closer relationships. When questioned why, participants stated construction frameworks provide closer and stronger relationships through longterm arrangements, thus resulting in a greater understanding between all participants and a higher level of response from suppliers to provide outcomes that meet client's expectations.

The positive results from the t-tests encouraged further enquiry using quantitative hierarchical regression analysis and this identified significant performance predictors/drivers for project outcomes as follows:

Task performance factors of suppliers assessed at the procurement phase were found to be the most significant predictors for project outcome of cost, and significant predictors for project outcomes of quality and closer relationships. Related performance drivers are project staff, competence of suppliers, execution approach, and structure of suppliers.
Contextual performance factors of suppliers assessed at the procurement phase were found to be the most significant predictors for project outcomes of time, quality, sustainability and closer relationships, and significant predictors for project outcome of cost. Related performance drivers include trust and collaboration, supplier's culture, and consciousness behaviour and attitude.

\section{Client's organisational factors adopted at procurement and construction phases were found to be significant predictors for project outcomes of time, quality, sustainability and closer relationships. Related performance drivers comprise incentives, performance monitoring, procurement approach, and communication.}

These causal relationships were explained and supported by the qualitative multiple-case study results, which demonstrated similar performance drivers. From this empirical evidence, the performanceimportance model (Figure 1) was successfully validated.

Results from the quantitative and qualitative analyses discussed in the previous chapter validate the hypotheses $\mathrm{RH} 2$ and $\mathrm{RH} 3$ and hence the performance improvement model (Figure 1), confirming that project outcomes of time, cost, quality, sustainability and closer relationships 
were all significantly driven by task performance, contextual performance and client's organisational factors.

Using this model, framework managers can manage the driving forces at the procurement and construction phases to achieve project outcomes. By reference to the task and contextual performance factors, this performance model can be used to select the best framework suppliers at the procurement phase. The model can also be used to drive the project performance by adopting the client's organisational factors at the procurement and construction phases.

\subsection{Recommendations for clients}

The performance improvement model can be used to select framework suppliers at the procurement phase by focusing on related task and contextual performance factors. The model also demonstrates that project performance can also be improved at procurement and construction phases by focusing on the client's organisational factors.

This research also confirms that the project outcomes of time, cost, quality, sustainability and closer relationships can be significantly improved when projects are delivered within suitably applied construction frameworks. It is recommended that public-sector clients use the performance improvement model to realise collaborative benefits and facilitate toward the UK Government construction strategy target of 33\% reduction in initial and whole life costs of built asset by 2025 .
It is also advised that the performance improvement model be applied to both new construction and maintenance framework projects in order to support sustainable development and management of the built environment.

Apart from the potential direct time and cost savings, the model can also support sustainable targets such as environmental improvements (reduction of carbon emission, water consumption and waste) and higher standards of health and safety (wellbeing and social sustainability) of the construction team at sites.

\subsection{Recommendations for}

\section{suppliers}

The performance improvement model is also useful to suppliers (contractors) who may wish to join a framework or participate in 'call off' work packages tendered through a framework. If suppliers can identify and communicate their individual strengths to clients with task and contextual performance, then the chances of winning work are increased.

A supplier's culture is the most significant performance predictor for three out of the five project outcomes (cost, quality and sustainability) and therefore adherence by a supplier to shared ownership of programmes, alignment with the client's culture, and shared learning and development is beneficial to achieving higher levels of performance.

Trust and collaboration are also a significant performance predictor for two outcomes (time and closer relationships). High levels of trust and 
respect for the client are associated with higher collaboration and speed in solving problems.

Other task and contextual performance skills that can drive project outcomes of time, quality and closer relationships are the supplier's project staff, competence, executive approach, structure of suppliers as well as conscious behaviour and attitude.

\subsection{Recommendations for government}

The strength of evidence and confirmed benefits from the use of construction frameworks support the strategic policies outlined by the UK government. The empirical evidence supports public sector policymakers in the use of frameworks.

This research also supports proposals made to address restrictions contained within the current Public Contracts Regulation 2015. Currently the maximum term of a framework agreement is four years and new suppliers are barred from joining an existing framework.

Proposals contained within the UK Government's Green Paper (Cabinet Office, 2020b) to remove the current maximum duration of four years to achieve value for money (following withdrawal from the European Union) coincides with longer term recommendations offered by this research.

It is also proposed that frameworks be open for new suppliers to join at defined points thereby addressing current concerns with competition and innovation.

\subsection{Recommendations for researchers}

Construction frameworks are regarded as an integrated, collaborative procurement method based on longterm relationships. The research confirms the significant impact of construction frameworks by aligning previous findings recognising connections between relationships and performance into the formal legislative framework arrangements.

As these formal arrangements have only been in existence under the Public Contract Regulations since 2015, and most frameworks are for four years duration, this research collates data from the first 'fully completed' frameworks controlled by these public sector rules.

Collation of data from 'real world' experiences of practitioners also enhances the depth and breadth of qualitative views on project outcomes and provides a robust, generalised performance-driving model. This indepth investigation provided by engagement with experienced professionals further adds knowledge on relational contracting and project management.

However, as the data provided toward the performance improvement model was developed through this research, the model should still be regarded as conceptual. It is recognised that public organisations, although sharing a similar organisational structure, have slightly different political constitutions and objectives and these may affect performance outcomes. 
Having stated that, every UK publicsector organisation has to comply with the Public Contracts Regulations 2015 and as these are prescriptive and detailed, it is expected that performance outcomes and performance driving measures from this research will be applicable to other similar organisations. Any variations, however, are expected to be minor and descriptive according to the definitions - for example, what is defined as quality or acceptable behaviours.

The performance improvement model was developed from investigation of two major tenets of public-sector organisations in the UK: namely infrastructure offices of public authorities and estate offices of the public universities. Although the chosen organisations provide typical environments which account for a substantial amount of public-sector expenditure, it is recommended that further research be extended to other public-sector organisations.

Finally, this research concentrates upon the relationship between clients and main contractors set within a public sector environment. Further research could be undertaken into relationships between main contractors and sub-contractors which involve the whole supply chain to identify the drivers of performance for these. In a similar but unconnected vein, there are also opportunities to examine those frameworks that exist outside of public sector legislation and are wholly set within the private sector.

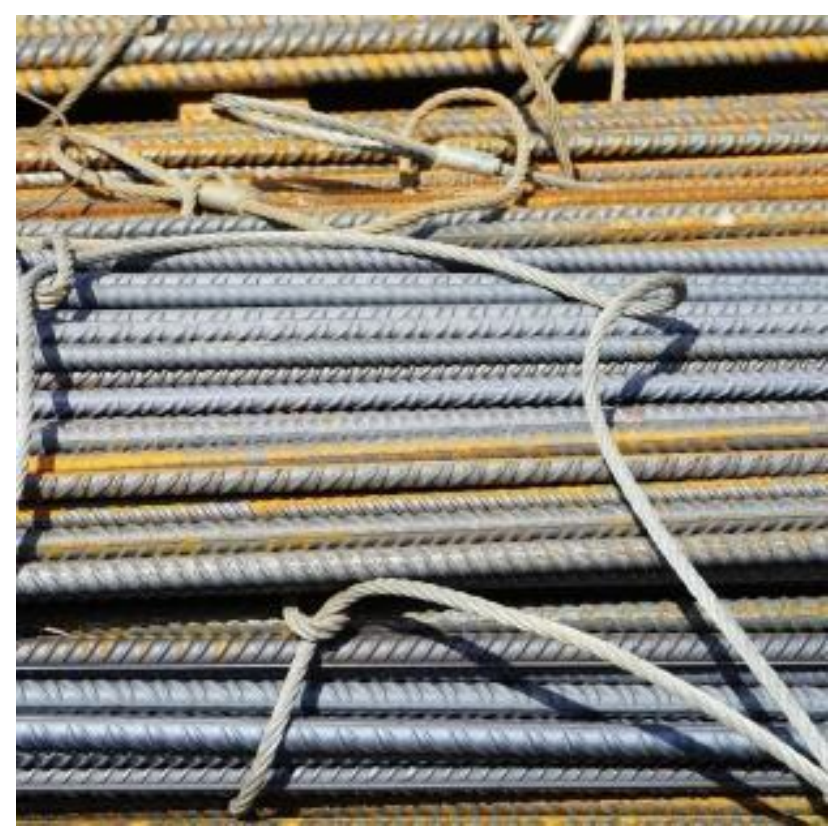




\section{References}

Akin, B. and Brooks, B. (2021), Total Facilities Management, Wiley-Blackwell, Oxford.

Audit Commission (2011), Going the Distance: Achieving Value for Money in Road Maintenance, Audit Commission, London.

BIS (2013). Industrial Strategy: government and industry in partnership, Construction 2025, London: Department for Business, Innovation \& Skills (BIS).

Bleda, M. and Chicot, J. (2020), The role of public procurement in the formation of market for innovation, Journal of Business Research, Vol. 107, No. 2, pp. 186-196.

Bresnen, M. and Marshall, N. (2000), Motivation, commitment and the use of incentives in partnerships and alliances, Journal of Construction Management and Economics, Vol. 18 Issue 5, 587-598.

Business and Enterprise Committee (2008), Construction Matters: Government Response to the Committee's Ninth Report of Session 2007-08, House of Commons, 14 November 2008, The Stationery Office Limited, London.

Butcher, D. C. A. and Sheehan, M. (2010), Excellent contractor performance in the UK construction industry, Engineering, Construction and Architectural Management, Vol. 17 Issue 1, pp. 35-45.

Cabinet Office (2011), Government construction strategy, Cabinet Office, London.

Cabinet Office (2020a) Cabinet Office Environmental Policy Statement, available at https://assets.publishing.service.gov.uk/government/uploads/system/uploads/att achment data/file/931371/Cabinet-Office-Environmental-Policy.pdf (accessed 17 December 2020).

Cabinet Office (2020b) Transforming public procurement, available at https://assets.publishing.service.gov.uk/government/uploads/system/uploads/att achment data/file/943946/Transforming public procurement.pdf (accessed 23 December 2020).

Coakes, S.J. and Steed, L.G. (2007), SPSS: Analysis without Anguish Using SPSS Version 14 for Windows, John Wiley \& Sons, Brisbane.

Constructing Excellence (2019a), What is a framework? available at http://constructingexcellence.org.uk/tools/frameworkingtoolkit/what-is-aframework/ (accessed on 18 October 2019).

Constructing Excellence (2019b), SCF - Intelligent Supplier Chain Management, available at https://constructingexcellence.org.uk/scf-intelligent-supply-chainmanagement/ (accessed on 24 February 2021).

Department of Education (2019), Construction Framework Handbook, available at https://www.gov.uk/government/publications/school-buildings-constructionframework/construction-framework-handbook (accessed on 18 October 2019).

Department of Environment, Food \& Rural Affairs (2015), 2010 to 2015 Government Policy: Sustainable Development, available at 
https://www.gov.uk/government/publications/2010-to-2015-government-policysustainable-development/2010-to-2015-government-policy-sustainabledevelopment (accessed 17 December 2020).

Egan, J. (1998), Rethinking Construction: Department of Trade and Industry (Construction Task Force), Her Majesty's Stationary Office, London.

Estate Management Office (2014), Customer Care Statement, Estate Management Office, Cambridge University, Cambridge.

Fellows, R. and Liu, A. (2015), Research Methods for Construction, Wiley Blackwell, Chichester.

Frontier Economics (2015) A Review of HEFCE Capital Expenditure, available at https://dera.ioe.ac.uk/23540/1/2015 capitalreview.pdf (accessed on 11 December 2020).

Kashiwagi, D. T. (2004), Best Value Procurement, Performance Based Studies Research Group (PBSRG), Arizona State University Press, Tempe, Arizona.

Koopmans, L., Bernaards, C.M., Hildebrandt, V.H., Schaufeli, W.B., De Vet, H.C.W. and Van der Beek, A.J. (2011), Conceptual frameworks of individual work performance - a systematic review, Journal of Occupational and Environmental Medicine, Vol. 53 No. 8, pp. 856-66.

Lahdenpera, P. (2011), Making sense of the multi-party contractual arrangements of project partnering, project alliancing and integrated project delivery, Construction Management and Economics, Vol. 30 Issue 1, 57-79.

Lam, T. and Gale, K. (2014a), Highway maintenance: impact of framework agreements on contractor performance, Engineering, Construction and Architectural Management, Vol. 21 Issue 3, pp. 336-347.

Lam, T. and Gale, K. (2014b), Highway maintenance: impact of framework agreements on project financial performance, Construction Management and Economics, Vol. 32 Issue 5, pp. 460-472.

Lam, T. and Gale, K. (2014c), Framework procurement for highways maintenance in the UK: Can it offer value for money for public clients, Structure and Infrastructure Engineering, Vol. 11 Issue 5, pp. 695-706.

Lam, T. and Gale, K. (2015), A Performance Model of Construction Frameworks, Journal of Engineering, Project and Production Management, Vol 5 (2), pp. 60-70.

Lam, T. (2017) Prediction of performance outcomes for procurement of public-sector construction consultants for property management, Property Management, Vol. 35, Issue 4, pp. 433-447.

Lam, T.Y.M. (2020a) A sustainable procurement approach for selection of construction consultants in property and facilities management, Facilities, Vol.38, No. $1 / 2$, pp. 98-113.

Lam, T.Y.M. (2020b) Driving sustainable construction development through postcontract key performance indicators and drivers, Smart and Sustainable Built Environment, vol. ahead-of-print, DOI 10.1108/SASBE-07-2020-0111. 
Latham, M. (1994), Constructing the team: final report of the government/industry review of procurement and contractual arrangements in the UK construction industry. London: Her MMSO.

Ling, Y. Y. (2000), A Theoretical Framework for Selection of Consultants by Designbuild Contractors, Journal of Construction Procurement, Vol. 6, No. 2, pp.147-63.

Local Government Association (2020), National Construction Category Strategy for Local Government: Effective Construction Frameworks, Local Government Association and National Association Construction Frameworks, available at https://yorhub.com/app/uploads/2021/02/4.106-Effective-ConstructionFrameworks-LGA-National-Construction-Strategy_01.pdf (accessed 2 March 2021).

Masa'deh, R., Obeidat, B.Y. and Tarhini, A. (2016), A Jordanian empirical study of the associations among transformational leadership, transactional leadership, knowledge sharing, job performance, and firm performance: A structural equation modelling approach, Journal of Management Development, Vol. 35 No. 5, pp. 681705.

McCracken, K. (2017), Council Forced to Cut Back on Highway Spending, available at https://www.rsta-uk.org/councils-forced-to-cut-back-on-highway-spending/ (accessed on 11 December 2020).

Morgan, A. (2009), I will not be taken for granted: BAA's boss on frameworks, Building Magazine, 26 June, pp. 6-9.

Morledge, R., Smith, A.J. and Appiah, S.Y. (2021), Building Procurement, WileyBlackwell, Oxford.

NEC4 (2017), New Engineering Contract 4 Framework Contract, Thomas Telford Limited, London.

Oyewobi, L.O., Abiola-Falemu, O. and Ibrironke, O.T (2016), The impact of rework and organisational culture on project delivery, Journal of Engineering, Design and Technology, Vol. 14 No. 2, pp. 214-237.

Office of National Statistics (2021), Construction Output in Great Britain: January 2021, Bulletin release dated 12 March 2021.

Office of Students (2019), The OfS Register, available at https://www.officeforstudents.org.uk/advice-and-guidance/the-register/existingregulatory-data/ (accessed on 28 February 2020).

Pallant, J. (2020), SPSS Survival Manual, Open University Press, London.

Patrucco, A.S., Luzzini, D. and Ronchi, S. (2017), Research perspectives on public procurement: Content analysis of 14 years of publications in the journal of public procurement, Journal of Public Procurement, Vol. 17, No. 2, pp. 229-269.

Sonnichsen, D. and Clement, J. (2020), Review of green and sustainable public procurement: Towards circular public procurement, Journal of Cleaner Production, Vol. 245, No 1, pp. 118-133.

Stanford, M.S and Molenaar, K.R. (2018), Influence of Simplified Procurement Methods on Competition for Public Sector Construction, Journal of Construction Engineering and Management, Vol. 144 Issue 2, pp. 108-121. 
Tellis, G.S., Prabhu, J.C. and Chandy, R.K. (2009), Radical innovation across nations: The pre-eminence of corporate culture. Journal of Marketing, Vol. 73 Issue 1, pp. 3-23.

Tennant, S. and Fernie, S. (2012), The commercial currency of construction framework agreements, Building Research \& Information, Vol. 40 Issue 2, pp. 209220.

Walker, A. (2011), Organizational Behaviour in Construction, Chichester: Wiley Blackwell.

Walker, A. (2015), Project Management in Construction, Chichester: John Wiley Blackwell.

Wondimu, P.A., Klakegg, O.J. and Laedre, O. (2020), Early contractor involvement (ECI): ways to do it in public projects, Journal of Public Procurement, Vol. 20, No. 1, pp. 62-87.

Xiao, H. and Proverbs, D. G. (2002a), The performance of contractors in Japan, the UK and the US: a comparative evaluation of construction cost, Construction Management and Economics, Vol. 20 Issue 5, pp. 425-435.

Xiao, H. and Proverbs, D. G. (2002b), Construction time performance: an evaluation of contractors from Japan, the UK and the US, Engineering, Construction and Architectural Management, Vol. 9 Issue 2, pp. 81-89.

Xiao, H. and Proverbs, D. G. (2002c), The performance of contractors in Japan, the UK and the US: a comparative evaluation of construction quality, International Journal of Quality and Reliability Management, Vol. 19 Issue 6, pp. 672-687.

Yeung, J. F.Y., Chan, A. P. C. and Chan, D. W. M. (2008), Establishing Quantitative Indicators for Measuring the Partnering Performance of Construction Projects in Hong Kong, Construction Management and Economics, Vol. 26, Issue. 3, pp. 277 301.

Yin, R.K. (2018), Case Study Research and Applications: Design and Methods, Sage Publishing, CA.

Zhang, S. B and Liu, M. M. (2006), Organizational culture profiles of construction enterprises in China, Construction Management and Economics, Vol. 24 Issue 8, pp 817-828. 


\section{Acknowledgements}

The authors would like to acknowledge the significant contributions received from the following people and organisations in completing this research:

All participants and practitioners from local authorities and university estate offices have been very forthright and generous with their views and time. In particular, their honest open engagement and willingness to share knowledge has been greatly appreciated. Their valuable time and support during collection of data for the expert pilot survey, a full questionnaire survey, multiple-case study interviews and site visits has provided a depth to this research by capturing their experiences of real-life scenarios.

The University of New South Wales, School of Built Environment for providing all necessary support.

Last but not least, the Property Research Trust for providing a research fund, encouragement and support to this project. 


\section{PROPERTY RESEARCH \\ TRUST}

